\section{Disputes about destruction}

\section{São Paulo}

By quoting figures that downplay the extent of Amazon deforestation, Brazil's President José Sarney last week touched off a dispute over estimates of rain-forest destruction and embarrassed his nation's own Instituto de Pesquisas Espaciais (INPE, Institute of Space Research).

Sarney's comments came as he signed into law legislation that creates the 'Nossa Naturenza' (Our Nature) programme (see Nature 338, 286; 23 March 1989).

He harshly attacked 'foreign intervention' in Brazil's Amazon policy and, to prove that the destruction of Amazon rain forest is not as bad as foreigners claim, he noted that the latest data on deforestation calculated by INPE scientists show that just 5.12 per cent of the rain forest has been cleared since the colonization of Brazil began in 1500 .

But that figure is in dispute. A 'green' federal deputy, social-democrat Fábio Feldmann from São Paulo, claimed the data had been 'manipulated' to suit government needs. The ' 5.12 per cent' derives from figures on the destruction of tropical ible for the analyis related the area destroyed $(250,429$ square kilometres) to the total area of the Brazilian Amazon region, designed to protect the Amazon forests moist forest. But the INPE team respons- rather than to the total area of rain forest,

Barbosa said the team did not relate deforestation data to total rain-forest area because "we do not know the true extent of the rain forest". But other INPE researchers said they thought it was a mistake to present the data that way. To pre-

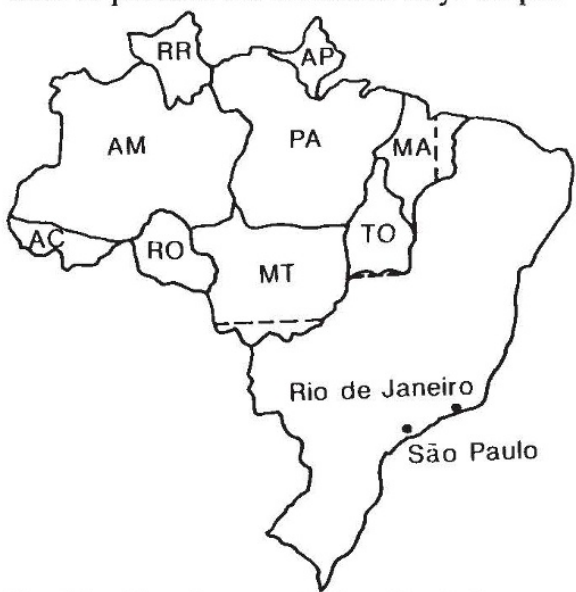

The Brazilian Amazon is legally defined as consisting of the whole of six states (Acre (AC), Amazonas (AM), Rondõnia (RO), Roraima (RR), Pará (PA) and Amapá (AP) and parts of three others (Mato Grosso (MT), Maranhão (MA) and Tocantins (TO). Only about three quarters of its $4,906,784$ square kilometres contains rain forest. The remainder consists of savannah. which is smaller (see map).

pare the report for the president, a task force was rapidly assembled and a building made over to it. In a vain attempt to prevent leaks to the press, INPE even moved its press officers away from the remote-sensing team.

Recalculation of the INPE figures using an estimate of the total area of rain forest $(3,700,000$ square kilometres) suggests that 6.8 per cent of the rain forest has been destroyed. But that figure is still much smaller than the 12 per cent deforestation claimed by the World Bank in its report Government Policies and Deforestation in Brazil's Amazon Region, released in January.

That figure is based largely on projections from Landsat data published in 1986 by Philip Fearnside, a US scientist working at the National Institue of Amazon Research at Manaus. But Fearnside himself estimates Amazon deforestation at 8 per cent. INPE's director-general, Márcio Noqueira Barbosa, says his institute's estimate is more accurate because it is based on 1988 Landsat images.

Landsat images are received every day at INP's station in Cuiabá, Mato Grosso. INP remote-sensing director Roberto Pereira da Cunha's team used Landsat Thematic Mapper data, with 30-metre resolution in the visible and near-infrared regions, to compile its data on deforestation. Cunha, who is clearly shaken by the controversy caused by the data, says they have studied 234 images, of which 104 were selected for detailed interpretation because they contained deforested regions. He claims the research began in August 1988 but this too is disputed. Other scientists say work began in earnest only in late March this year.

\section{Ricardo Bonalume Neto} 24 nations at last month's environment conference at the Hague (see Nature 338, $193 ; 1989$ ) has provoked an angry reaction in Brazil. The advertisement appeared on Monday, 3 April in all 24 signatory countries, but the version in Le Monde, Figaro and Libération, published at a cost of FF1.8 million $(\$ 290,000)$ to the prime minister's information service, reproduced the signatures of the 24 national representatives alongside an additional statement which, it seems, was not part of the declaration.

The statement says that the 24 signatories call for the creation of "a worldwide authority, invested with real decisionmaking and executive powers to save the atmosphere". The statement also says that the signatories are "ready to surrender part of their national sovereignty for the common good of humanity as a whole".

Paulo Tarso Flecha de Lima, the Brazilian diplomat whose signature appears in the advertisement, was not prepared to go this far at the Hague. The Brazilian government, criticized for destruction of its rain forests, has angrily resisted attempts by other nations to enforce a policy of conser- vation. Brazilian President José Sarney recently accused the foreign media of conducting an "alarmist campaign" against Brazil and complained that developed countries were backing policies that would make Brazilians "slaves".

The United States, which did not send a representative to the Hague meeting, also has no enthusiasm for a new worldwide authority. At a congressional briefing last week, William A. Nitze, a US State Department representative, said it was "premature to be considering a 'law of the air' or supranational authorities to deal with climate change".

With European elections in full swing in France, concern for the environment has become a campaign issue. Opinion polls following a good result in recent municipal elections have shown the hitherto dormant French ecology party to be an emerging alternative centre force and both the incumbent socialists and the right-wing opposition have been scrambling to demonstrate their interest in environmental issues. That may partly explain the government's decision to advertise the Hague declaration with President François Mitterrand's signature prominently on display.

Peter Coles

\section{$\mathrm{SSC}$}

\section{India offers help}

\section{New Delhi}

INDIA is proposing to participate in the US Superconducting Super Collider (SSC) project by contributing manpower and equipment but not money, according to Science Minister K. R. Narayanan. He told parliament last week that informal discussions had taken place between Indian and US scientists but "no formal agreement has been signed nor any commitment on expenditure agreed to".

Narayanan said India was joining the SSC project because it provided "a good opportunity for Indian scientists to work at the frontiers of science and technology".

A spokesman for the Indian team negotiating with the SSC project authorities confirmed an Indian offer of $\mathbf{\$ 5 0}$ million in hardware, particularly particle detectors, but "there is not going to be any monetary contribution at all", he said. K.S. Jayaraman 